\title{
イネ稲こらじ病粒のウスチロキシン A の含有量に拈ける菌株間の差異
}

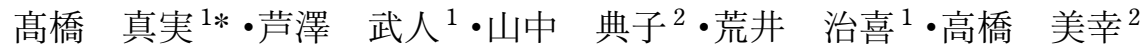

\begin{abstract}
TAKAHASHI, M. ${ }^{1 *}$, ASHIZAWA, T. ${ }^{1}$, YAMANAKA, N. ${ }^{2}$, ARAI, M. ${ }^{1}$ and TAKAHASHI, Y. ${ }^{2}$ (2012) Pathogenic isolates of Ustilaginoidea virens differ greatly in their production of ustiloxin A in rice false smut balls. Jpn. J. Phytopathol. 78: 305-308.

A protocol to quantify ustiloxin A (ustA) in a bulk sample of false smut balls of rice (J. Vet. Med. Sci. 71: 239-241) was modified to quantify ustA in single balls collected from a paddy field after natural infection and in balls formed after rice plants were inoculated with either of two isolates of Ustilaginoidea virens isolated from different commercial fields in Fukui Prefecture. To test whether these isolates differed in their capacity to produce ustA, we compared the mean quantity of ustA that each produced in individual balls. The two isolates varied greatly in ustA production; the differences in ustA in balls between the two ranged from 42 -fold to 115 -fold. Such massive differences in ustA production indicate that the pathogenic isolate is an important contributing factor to the quantity of ustA produced in false smut balls.
\end{abstract}

(Received February 17, 2012; Accepted May 2, 2012)

Key words: rice, rice false smut, quantitative detection, ustiloxin A, mycotoxin

イネ稲こうじ病菌［Ustilaginoidea virens (Cooke) Takahashi, teleomorph: Villosiclava virens E. Tanaka \& C. Tanaka]（Tanaka et al., 2008）の感染により穂に形成される病粒には, ウスチ ロキシン A が含まれる，ウスチロキシン A は，微小管タン パク質の重合の阻害作用, 培養細胞への毒性が明らかになっ て抢り，マウスへの投与実験により肝臓，腎臓，前胃に障害 を起こすことが確認されている (Koiso et al., 1992; Koiso et al., 1994; 仲村ら，1992）。このよらに浮乳類に対して毒性を示す ことから, 食用米や飼料米の污染による人や家畜への影響が 粵念されている. 安全性を確保するために, 病原菌のウスチ ロキシン A の産生や蓄積に関する研究を進める必要がある. そのためには，適切な定量法が必要である。

これまでに家畜の飼料用のサイレージ $5 \mathrm{~g}$ や病粒 $24 \mathrm{~g}$, $110 \mathrm{~g}$ からウスチロキシン A を抽出して定量がおこなわれた (Koiso et al., 1994; Miyazaki et al., 2009). しかし，病原菌の毒 素産生の解析に扔いては, さらに少量のサンプルから定量す る方法が求められる.

稲こうじ病菌は, 開花前の頑花に侵入して病粒を形成する
が（芦澤・片岡，2005; 池上，1959; 園田，1996），感染過程 の詳細は明らかではない，藤田ら（1989）は，接種試験の結 果から, 出穂前の特定の発達過程の穎花が感染し易いと考察 している. 感染した穎花では, 菌が内部で充満して膨らみ, 外穎と内穎の間から露出して, 暗緑色の厚壁胞子に覆われた 病粒となる（園田，1996）。池上（1959）は，複数個の病粒が 存在する穂を観察して, 病粒の存在位置から, 同一穂に存在 する病粒は, 共通の感染源から派生する場合が多いと考察し ている，頑花は比較的に閉鎖的な環境であり，病原菌が須花 の中に次々と侵入するとは考兄にくい，さらに，感染した頑 花ごとに病粒を形成していくので, 個々の病粒を定量の単位 とすれば, 由来の異なる複数の病原菌の産生毒素を量る可能 性は低くなると考兄られる。また，病粒は，採集が簡単で扱 い易い。これらの理由から，個々の病粒を定量の対象とする ことは, 菌株の毒素産生能力の評価や経時的な蓄積量の評価 等に適していると考兄られる。 また，圃場で発生した病粒数 を知ることが可能なので, 病粒当たりの含有量から毒素量を 推定する等の利用も期待できる，我々は， 1 病粒中のウスチ

\footnotetext{
1 農業・食品産業技術総合研究機構中央農業総合研究センター北陸研究センター（テ 943-0193 新潟県上越市稲田 1-2-1） Hokuriku Research Center, NARO Agricultural Research Center, 1-2-1 Inada, Joetsu, Niigata 943-0193, Japan

2 農業・食品産業技術総合研究機構動物衛生研究所（干 305-0856 茨城県つくば市観音台 3-1-5） NARO Institute of Animal Health, 3-15 Kannondai, Tsukuba, Ibaraki 305-0856, Japan

* Corresponding author (E-mail: mamitaka@affrc.go.jp)
} 
ロキシン A の定量法を検討した. さらに, 稲こうじ病菌株及 び宿主であるイネ品種がウスチロキシン A 産生に及ぼす影 響を解析した。

1 病粒中のウスチロキシン A の定量 $24 \mathrm{~g}$ の病粒からウス チロキシン A を定量した Miyazaki et al. (2009) による方法 を, 1 病粒（約 $30 \sim 200 \mathrm{mg}$ ) の定量が可能となるように改 変し, 新潟県上越市の稲こうじ病が常発する戋場で 2011 年 に栽培された「コシヒカリ」から 6 病粒,「夢あ拉ば」から 6 病粒を採集して, 1 病粒中のウスチロキシンAの定量を試 みた。病粒は, 一週間風乾後, 定量した。 1 病粒を, ジリコ ニアシリカビーズ $(0.6 \mathrm{~mm}) 0.5 \mathrm{~g}$ とステンレスビーズ $(6 \mathrm{~mm})$ 1 個と共に $2 \mathrm{ml}$ 容量のチューブに入れ, $1 \mathrm{ml}$ の蒸留水を加え た.これをあらかじめ $-20^{\circ} \mathrm{C} に$ 冷却したチューブホルダーに セットし，1000 rpmで 3 分間破砕処理した（シェイクマス ターオート, (株) バイオメディカルサイエンス). 蒸留水を 加えてから破砕処理したのは, 温度上昇を抑制する効果を期 待したからである. 破砕処理後に 30 分間振とらして(キュー トミキサーCM-1000, 東京理化), ウスチロキシン Aを抽出 した.これを $15,000 \mathrm{rpm}$ で 15 分間遠心分離して, 上清を回 収した。沈殿には $1 \mathrm{ml}$ の蒸留水を加えて, 再度, 破砕処理, 振とう, 遠心分離を繰り返して, 合わせて $2 \mathrm{ml}$ の抽出液を 得た。

続いて，抽出液 $1 \mathrm{ml}$ を Sep-Pak ${ }^{\circledR}$ Plus C18 cartridge（充填 量 $360 \mathrm{mg}$ 日本ウォーターズ）で処理した. カラムは, メタ ノール $5 \mathrm{ml}$, 水 $5 \mathrm{ml}$ を通した後, サンプル $1 \mathrm{ml}$ を加えて保 持させて, $5 \mathrm{ml}$ の水で 3 回洗浄した後に, $5 \mathrm{ml}$ の 20\%エタ ノール（v/v）で抽出した. このサンプル $20 \mu \mathrm{l}$ にいて高速 液体クロマトグラフィー（LC-10Ai 島津製作所）を行い， ウ スチロキシン A のピークを同定した. カラムは, Wakocil-II
5C18 RS（250 mm × $4.6 \mathrm{~mm}$ Wako）を用い，移動相は，水， メタノール，リン酸 $[400: 100: 1(\mathrm{v})]$ とし, $0.5 \mathrm{ml} /$ 分の 流速で分離した. 動物衛生研究所が東京大学より分譲を受け たウスチロキシン $\mathrm{A}$ の標品で定量したウスチロキシン $\mathrm{A}$ 粗 抽出物をワーキングスタンダードとし (Miyazaki et al. , 2009），分析值を比較して病粒の抽出液の濃度を求めた。供 試した 12 病粒すべてで， ウスチロキシン A のピークが認め られ, 定量可能であった. 個々の病粒のウスチロキシンAの 含有量を第 1 表に示した，病粒当たりの含有量の平均值（標 準偏差）は，「コシヒカリ」に形成された病粒では， $24.3 \mu \mathrm{g}$ (19.8)，「夢あ拈ば」では $22.1 \mu \mathrm{g}(26.0)$ であった。病粒 $1 \mathrm{~g}$ 当たりの含有量の平均值は,「コシヒカリ」の病粒では $334.3 \mu \mathrm{g}(182.0)$ ，「夢あ抋ば」では $159.2 \mu \mathrm{g}$ (104.6)であった.

あらかじめ既知の量のウスチロキシン A を加えたサンプ ルについて，前述の方法で定量し，回収率を調べた。夢あお ばの病粒 2 個を乳鉢で軽く磨砕し，よく混ぜて均一とした後

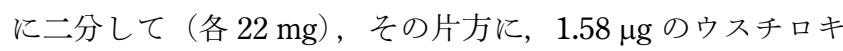
シン $\mathrm{A}$ を含む粗抽出物を加えた。 これらを定量した結果，各 サンプルのウスチロキシン A 量は, $4.58 \mu \mathrm{g}$ 及び $3.36 \mu \mathrm{g} て ゙$ あった. 2 サンプルの差は $1.22 \mu \mathrm{g}$ であり，添加した $77.2 \%$ のウスチロキシン A が回収されたと考えられた。

以上のよらに，本研究で検討した方法により，圃場で自然 発生した 12 病粒すべてについて定量することができた. 1 病 粒のようにサンプルが少量であれば, 破砕処理時に容器に付 着して回収できないサンプル量の割合が多くなるために，正 確な測定が困難となる。しかし，本法は，ビーズ式破砕機を 使用して，1つのチューブ内で破砕から抽出までを行うこと から，測定が可能であったと考えられる.

病粒の毒素含有量の菌株及び宿主品種による差 菌株及

第 1 表 上越市の煵場で採集された病粒のウスチロキシン $\mathrm{A}$ の含有量

\begin{tabular}{|c|c|c|c|c|}
\hline 宿主品種 & サンプル番号 & 病粒の重量（mg） & 1 粒当たりの含有量（ $\mu \mathrm{g} ）$ & $1 \mathrm{~g}$ 当たりの含有量 $(\mu \mathrm{g})$ \\
\hline \multirow{7}{*}{ コシヒカリ } & 1 & 32.2 & 7.3 & 227.5 \\
\hline & 2 & 43.3 & 7.7 & 177.9 \\
\hline & 3 & 53.4 & 14.7 & 275.2 \\
\hline & 4 & 76.7 & 47.8 & 623.2 \\
\hline & 5 & 102.4 & 50.9 & 496.5 \\
\hline & 6 & 84.5 & 17.4 & 205.8 \\
\hline & 平均 & 65.4 & 24.3 & 334.3 \\
\hline \multirow{7}{*}{ 夢あおば } & 1 & 46.9 & 5.8 & 123.5 \\
\hline & 2 & 62.7 & 5.0 & 79.8 \\
\hline & 3 & 90.8 & 9.8 & 107.8 \\
\hline & 4 & 129.5 & 25.9 & 200.3 \\
\hline & 5 & 146.4 & 13.1 & 89.7 \\
\hline & 6 & 206.0 & 72.9 & 354.1 \\
\hline & 平均 & 113.7 & 22.1 & 159.2 \\
\hline
\end{tabular}


第 2 表 稲こうじ病菌株（U2006-8 及び U2006-9）の接種により，「コシヒカリ」，「夢あおば」に形成された病粒のウスチロキシンA の含有量

\begin{tabular}{|c|c|c|c|c|c|c|c|c|}
\hline \multirow{3}{*}{ 菌株名 } & \multicolumn{4}{|c|}{ コシヒカリ } & \multicolumn{4}{|c|}{ 夢あおば } \\
\hline & \multicolumn{2}{|c|}{1 粒当たり } & \multicolumn{2}{|c|}{$1 \mathrm{~g}$ 当たり } & \multicolumn{2}{|c|}{1 粒当たり } & \multicolumn{2}{|c|}{$1 \mathrm{~g}$ 当たり } \\
\hline & 含有量（ $\mu \mathrm{g} ）$ & 標準偏差 & 含有量（ $\mu \mathrm{g} ）$ & 標準偏差 & 含有量（ $\mu \mathrm{g} ）$ & 標準偏差 & 含有量（ $\mu \mathrm{g} ）$ & 標準偏差 \\
\hline U2006-8 & 1.6 & 0.8 & 22.9 & 10.0 & 2.9 & 1.4 & 35.0 & 8.8 \\
\hline U2006-9 & 116.7 & 25.6 & 1539.1 & 591.6 & 51.6 & 17.1 & 1117.3 & 449.4 \\
\hline
\end{tabular}

第 3 表 稲こうじ病菌株（U2006-8 及び U2006-9）の接種により，「あきたこまち」，「ホシアオバ」に形成された病粒のウスチロキシ ン $\mathrm{A}$ の含有量

\begin{tabular}{cccccr}
\hline \multirow{2}{*}{ 菌株名 } & \multicolumn{3}{c}{ あきたこまち } & \multicolumn{3}{c}{ ホシアオバ } \\
\cline { 2 - 3 } & 1 1 粒当たり含有量 $(\mu \mathrm{g})$ & $1 \mathrm{~g}$ 当たり含有量 $(\mu \mathrm{g})$ & & 1 粒当たり含有量 $(\mu \mathrm{g})$ & $1 \mathrm{~g}$ 当たり含有量 $(\mu \mathrm{g})$ \\
\hline $\mathrm{U} 2006-8$ & 1.8 & 24.3 & 1.2 & 14.7 \\
$\mathrm{U} 2006-9$ & 115.0 & 1347.1 & 90.2 & 1691.8 \\
\hline
\end{tabular}

びイネ品種の違いが毒素産生に及ぼす影響を解析するため に, Ashizawa et al. (2011) の方法に従った人工接種により, 温室内で形成された病粒について, 前述の方法で定量した. 「コシヒカリ」,「夢あ拈ば」の 2 品種に稲こうじ病菌 2 株 （U2006-8, U2006-9）の分生子をそれぞれ接種した. いずれの 供試菌株も, 2006 年に一般圃場で発生した病粒から分離した ものであり, U2006-8 は, 福井県吉田郡永平寺町で, U20069 は, 福井県福井市大宮町で採取された。 これらの菌株は, ジャガイモ煎汁寒天培地上の菌の増殖速度に差が見られず, イネに接種した時の病徵や病粒形成数にも特段の違いは認 められなかった．接種は，2010年 7 月 8 日（「夢あおば」）と 7 月 17 日（「コシヒカリ」）に行い, 病粒は出穂 20 日後に採 集した（「夢あ批」 8 月 11 日，「コシヒカリ」 8 月 17 日）. 病粒は, 皮膜が破れて, 暗緑色であった。病粒は, 風乾後 $4^{\circ} \mathrm{C}$ で保存した。接種したイネ品種と菌株が共通する実験ご とに, 3 病粒あるいは 5 病粒のウスチロキシン A を定量した. 定量の結果を第 2 表に示す. 各病粒の定量結果を $1 \mathrm{~g}$ 当た りに換算して, 菌株及び品種の含有量に対する影響を共分散 分析（統計解析ソフトウェア R ver. 2. 13.0）で評価した. そ の結果, 菌株と品種の交互作用は, 有意ではなかった $(P=$ 0.2589).ささらに, 交互作用がないとして品種と菌株の効果を 調べた。 その結果, 品種による効果は有意でなかった $(P=$ $0.2905)$ が, 菌株による効果は有意であった $\left(P=1.058 \mathrm{e}^{-5}\right)$. 2 品種の U2006-9 による病粒の定量値（1 g 当たりのウスチ ロキシン $\mathrm{A}$ の含有量) から求めた平均值は, U2006-8 による 病粒の平均値と比較して 42 倍であった.

U2006-8 と U2006-9 のウスチロキシンAの産生量の差異を 確認するために，「あきたこまち」と「ホシアオバ」にも接
種を行い，形成された病粒について定量した，接種及び病粒 形成は,「コシヒカリ」と「夢あおば」の場合と同様な方法 で扎こなった。 3 病粒を合わせて定量し，病粒 1 粒当たりと 病粒 $1 \mathrm{~g}$ 当たりの含有量を求めた (第 3 表).「コシヒカリ」と 「夢あ据ば」接種試験と同様に，「あきたこまち」と「ホシ アオバ」の場合も品種間では含有量に大きな差が認められな かった.しかし，U2006-9 の病粒の $1 \mathrm{~g}$ 当たりの含有量は， U2006-8 の病粒と比較して，「あきたこまち」では 55 倍，「木 シアオバ」では 115 倍であった.

感染初期のウスチロキシン $\mathrm{A}$ の蓄積について知見を得るた めに，U2006-8 及び U2006-9 を「あきたこまち」，「ホシアオ バ」にそれぞれ接種し，出穂後 3 日から 5 日経過した穎花に ついても定量を試みた. 穎花は, 実体顕微鏡で観察すると, 外 穎と内穎がわずかに開き，白みがかったオレンジ色の稲こら じ病の菌体が認められた. 穎花は，3個あわせて定量した.

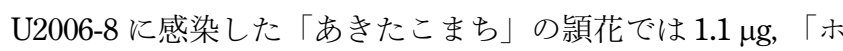
シアオバ」では $2.1 \mu \mathrm{g}, \mathrm{U} 2006-9$ に感染した「あきたこまち」

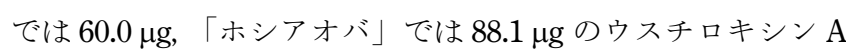
が検出された。 このように，病粒形成の初期であってもすで にウスチロキシン $\mathrm{A}$ が産生されていることが明らかになっ た.この結果から，稲こうじ病が常発する圃場では，目視に よって病粒が確認できない早期に収穫した飼料にも, ウスチ ロキシンAが含まれている可能性があると考えられた.

「コシヒカリ」,「夢あ执ば」の接種試験により，ウスチロキ シン $\mathrm{A}$ の含有量に対して菌株の違いが有意であることが示さ れ，「あきたこまち」，「ホシアオバ」での接種試験でも菌株間 で明瞭な差が認められた。 どの試験に扣いても菌株間の含有 量の差は大きく，42 倍以上であった。この結果から，菌株が 
ウスチロキシン A の産生量に大きく影響する因子であること が明らかである。また，自然発生圃場から採取された病粒間 でも 1 粒当たりの含有量で 15 倍, $1 \mathrm{~g}$ 当たりの含有量で 8 倍 の差異が検出された (第 1 表). 以上より, 生産物のウスチロ キシン A の污染程度を予測するには, 収穫物がどのよらな毒 素産生能力を持つ菌によって污染されたのかを評価すること が重要であり, 病粒あるいは収穫物の一部について毒素含有 量を測定することが不可欠であると考えられた.

今後, 本研究で示したよらに, 病粒形成法 (Ashizawa et al., 2011）と 1 病粒中のウスチロキシン A の定量法を組み合わせ た解析を行ならことにより, 稲こうじ病菌の毒素産生に係る 生理学的研究の進展が期待できる.

本研究を実施するにあたり, 動物衛生研究所の宮崎茂氏, 吉岡都氏, 嶋田伸明氏に分析に関する助言及び指導を賜っ た. 中央総合農業研究センター北陸研究センターの高橋明彦 氏には, 統計解析の指導を賜った. ここに記して感謝の意を 表する.

\section{引用文献}

芦澤武人・片岡由希子 (2005). イネ稲こうじ病菌特異的プライ マーを用いた Nested-PCR による戋場に栽培された出穂前 後の穂からの検出. 日植病報 71: 16-19.
Ashizawa, T., Takahashi, M., Moriwaki, J. and Hirayae, K. (2011). A refined inoculation method to evaluate false smut resistance in rice. J. Gen. Plant Pathol. 77: 10-16.

藤田佳克・園田亮一・八重樫博志 (1989). 稲こうじ病菌分生胞 子のイネ穂ばらみ期接種. 日植病報 55: 629-634.

池上八郎 (1959)。稲域病に関する研究 III. 穂における病籾の 発生と被害解析. 岐阜大農研報 11: 56-63.

Koiso, Y., Natori, M., Iwasaki, S., Sato, S., Sonoda, R., Fujita, Y., Yaegashi, H. and Sato, Z. (1992). Ustiloxin: A phytotoxin and a mycotoxin from false smut balls on rice panicles. Tetrahedron Lett. 33: 4157-4160.

Koiso, Y., Li, Y., Iwasaki, S., Hanaoka, K., Kobayashi, T., Sonoda, R., Fujita, Y., Yaegashi, H. and Sato, Z. (1994). Ustiloxins, antimitotic cyclic peptides from false smut balls on rice panicles caused by Ustilaginoidea virens. J Antibiot. 47: 765-773.

仲村賢一・泉山七生貴・大坪浩一郎・小磯邦子・岩崎成夫・ 園田亮一・藤田佳克・八重樫博志・佐藤善司 (1992). Ustilaginoidea 産生トキシンの phomopsin A の類似作用一マウス による急性毒性実験一. マイコトキシン 35: 41-43.

Miyazaki, S., Matsumoto, Y., Uchihara, T. and Morimoto, K. (2009). High-performance liquid chromatographic determination of ustiloxin A in forage rice silage. J. Vet. Med. Sci. 71: 239-241.

園田亮一 (1996). 稲こうじ病の発生生態と防除法. 植物防疫 50 : 351-354.

Tanaka, E., Ashizawa, T., Sonoda, R. and Tanaka, C. (2008). Villosiclava virens gen. nov., comb. nov., teleomorph of Ustilaginoidea virens, the causal agent of rice false smut. Mycotaxon 106: 491-501. 